\title{
Monogyny and polygyny in the life of the ant nest
}

\author{
Моногиния и полигиния в жкизни муравейника
}

\begin{abstract}
A.A. Zakharov
A.A. Захаров

A.N. Severtzov Institute of Ecology and Evolution, Russian Academy of Sciences, Moscow 119071, Russia. E-mail: ferda@bk.ru Институт проблем экологии и эволюции имени А.Н. Северцова РАН, Москва 119071, Россия.

KEY WORDS: ants, monogyny, polygyny, social structures, development of ant nest.

КЛЮЧЕВЫЕ СЛОВА: муравьи, моногиния. полигиния, социальные структуры, развитие муравейника.
\end{abstract}

ABSTRACT. Possibility of a primary polygyny is originally included into the scenario of pleometrosis. Competition of the queens for food, care and attention of the workers is the main factor motivating the choice between monogyny (MG) and polygyny (PG) in ants. The number of queens does not impose the ban on any key features of the society. Development of different features, i.e. foundation of a new family by young queens as well as presence of auxiliary nests (polycaly), sociotomy, permanent superfamilial structures is possible under both conditions (MG/PG) but they are acquired by partially different ways. Like other features, MG/PG condition is related to size, level of organization at different stages of life history and conditions of origin of the community.

РЕЗЮМЕ. Возможность первичной полигинии изначально заложена в сценарии плеометроза. Конкуренция самок за корм, уход и внимание со стороны рабочих - основной фактор, мотивирующий выбор между моногинией (МГ) и полигинией (ПГ). Число самок не накладывает запрета ни на одну из узловых функций муравейника. В обоих вариантах (МГ или ПГ) возможны: основание новой семьи молодой самкой, вспомогательные гнезда (поликалия), социотомия, постоянные надсемейные структуры, однако эти возможности реализуются частично различающимися путями. Как и другие свойства общины, состояния МГ/ПГ связаны с ее размерами, уровнем организации на разных этапах жизненной истории и условиями их прохождения.

\section{Introduction}

The number of queens in the family is of fundamental importance in the life of ant communities. Changes in this number have significant implications for the organization of each individual nest and for the local populations that include those nests. There are several aspects of this problem. On one hand, the number of females, i.e. monogyny (MG) or polygyny (PG), should determine basic properties of the social organization of the ant society [Bourke, Franks, 1995; Keller, 1995]. On the other hand, the number of females in the nest of a given species varies widely (from one to several hundred), changing both at different stages of the colony's life [Pisarski, 1982; Schrempf, Heinze, 2007] and during the annual cycle, as was shown in the case of Linepithema humile (Mayr, 1868) [Keller et al., 1989]. In addition, the number of queens varies depending on the conditions in different parts of the habitat [Bourke, Franks, 1995; Bondar, Rusina, 2003] and biotopes (e.g. [McGlynn, 2010]). The transition of MG to PG follows the species expansion to the North [Henze, Hölldobler, 1994] or its introduction into new regions [Tsutsui, Suarez, 2003]. However, population-based studies of the imported fire ant Solenopsis invicta Buren, 1972 have shown presence of polygyny in its original habitat as well [Jovenaz et al., 1989].

The above information suggests that the number of queens can be as variable as most other characteristics of the ant society. Ants alter the number of queens according to the size and age of the society, climate and spatial conditions, nest organization, population density, environmental factors, etc. This situation can be explained by the fact that the ant society is a biosocial system that displays priority of social driving forces over all other ones. This is supported by the phenomenon of mixed formicaries [Zakharov, Zakharov, 2011] and by the strategy of population concentration, both present in all subfamilies of the Formicidae [Zakharov, 2011]. It is therefore obvious that primary goals of any social system are self-preservation and transition to the definitive level.

At the same time, we should remember that subjective characteristics of most species, including occurrence of MG/PG (e.g. [Debout et al., 2007]) are incomplete and approximate. Indeed, even a single event of polygyny indicates presence of this phenomenon in a normally monogynous species. 


\section{Prerequisites for formation of the polygy- nous settlements in ants}

Any factors/properties that directly determine the choice between MG and PG usually cannot be identified. Nevertheless, we can determine a number of traits that make formation of the stable polygynous settlements possible. The general prerequisites for the transition of MG to PG include: tolerance of the developed sociality to deviations from the normal condition [Fedoseeva, 2003]; inability of foundresses to distinguish between related and foreign queens as well as between their broods [Bernasconi, Strassmann, 1999]; failure of young workers to distinguish between their mother and foreign queens [Evesham, 1985], brood keeping without cells [Zakharov, 1991]. Under independent family foundation, primary polygyny is inherent in the scenario of pleometrosis. Review of the fundamental characteristics of associations of the foundresses was made by Bourke and Franks [1995]. Here are their main conclusions: (1) associations of the foundresses consist of unrelated queens (e.g. [Rissing, Pollock, 1988; Hagen et al., 1988]), (2) all those females are usually egglaying (e.g. [Rissing, Pollock, 1988]), and (3) those associations usually develop into monogynous families [Heinze, 1993]. However, a direct transition from pleometrosis to primary polygyny was observed in Iridomyrmex purpureus (Smith, 1858) [Batz, Holldobler, 1982], Atta texana (Buckley, 1860) [Mintzer, 1987] and Acromyrmex versicolor (Pergande, 1893) [Rissing et al., 1989].

A number of factors promote formation of pleometrosis and primary polygyny. One of those factors is the lack of competition among foundresses during formation of their associations as well as high tolerance of ants to foreign individuals in the period of brood raids between family cells [Tschinkel, 1992; Krasilnikov, 1998; Zakharov , 2001]. Another factor is presence of specific goals that can only be achieved by a group of individuals during nest foundation, as in Oecophylla Smith, 1860 [Peeters, Andersen, 1989]. The efficiency of joint actions of several foundresses has been demonstrated in egg-laying and nest defense [Tschinkel, 1992; Bourke, Franks, 1995], as well as in adverse conditions, e.g. in winter. This can be observed in Camponotus Mayr, 1861 that demonstrates high mortality of single foundresses during the winter [Henze, Hölldobler, 1994].

It is worth noting that pleometrosis is an "ontogenetic" evidence for the parasocial development of sociality in insects [Dlussky, 1984]. Parasocial tendencies also can be observed during other stages of the family life of ants. Those tendencies certainly played an important role in the development of polygyny and the queen replacement mechanisms [Zakharov, 1991]. While the parasocial pathway was earlier considered as one of the two models of the evolution of eusociality, i.e. subsocial and parasocial ones [Wilson, 1971], the last modification of the model of the evolution of eusociality gives priority to the parasocial pathway [Novak et al., 2010]. However, kin-selection theory supporters believe that MG is primary in ants and that PG is a secondary phenomenon, or even a paradox that creates problems for the theory itself [Keller, 1995] as well as for the life history theory [Starr, 2006]. In most cases, the process is therefore considered as the development of polygynous structures from the ancestral monogynous state [Bourke, Franks, 1995; Schrempf, Heinze, 2007]. However, the key mystery in the case of pleometrosis is that species cannot retain polygyny during the initial stages of social development of the nest. Moreover, if pleometrosis in most species ends with the transition to monogyny, it is unclear why the mature society needs secondary polygyny. However, the conflict of interests within the ant society seems to be a possible answer.

\section{Competition}

Competition in ant communities manifests itself at all levels. Workers compete for the right to get engaged in certain activities, for leadership in their functional group, and for the best individual foraging areas. Ant societies of the same species compete for food, territory, and nesting sites, and, in multispecies communities, also for the status in the community.

Queens in the same nest also develop competitive relationships [Wilson, 1971; Zakharov, 1991; Heinze, 1993]. The main objects of their competition are availability of food, care and attention from the workers. If there are enough workers, the competition is relatively weak. However, lack of workers is the basis for fierce competition. At the initial stage of the family development, foundresses do not have objects to compete for, since those foundresses provide their food supplies themselves in the absence of workers. As soon as first workers appear, however, they become the subject of competition that intensifies if the density of workers decreases together with an increase in the number of queens. The need of the queens for having more workers can stimulate the beginning of raids between the nests at any moment. For example, Solenopsis invicta has been experimentally shown to increase raid activity with the change of the number of queens in the nest from one to four [Adams, Tschinkel, 1995]. Tension is relieved if females spread out to different parts (cells) of the nest or to different nests. This has been shown for species with the observed direct transition from pleometrosis to primary polygyny, i.e. in Atta texana [Mintzer, Vinson, 1985; Mintzer, 1987], Iridomyrmex purpureus [Hölldobler, Carlin, 1985] and Formica fusca Linnaeus, 1758 [Zakharov, 2001, 2011]. The number of females in the polysectional nests of desert ants is determined by the number of sections within the nest [Dlussky, 1981]. 
The transition from pleometrosis to primary polygyny

This transition becomes possible if each queen has a dedicated group of worker ants that provide her with food and care for her and for the brood. A sufficient number of workers and/or spatial separation of queens is required to satisfy those conditions which are also met in the examples described above. Specifically, the trend towards the spatial dissociation of the queens during the initial stages of nest foundation is observed in several species [Hölldobler, Carlin, 1985; Zakharov, 2001].

To summarize, we hypothesize that all species that display pleometrosis can also implement the transition to primary polygyny. Conditions of such transition are variable and not always clear, and this is probably the main cause of the detection of monogyny after the appearance of the first workers in laboratory experiments.

The number of queens and key events in the life of the ant society

Several parameters of the ant society certainly have something to do with the number of queens. Polygyny increases the total reproductive capacity of the family [Zakharov, 1991] and reduces its vulnerability to various environmental factors [Starr, 2006]. Polygyny stimulates formation of the subordinate structures within the society that in turn lift restrictions on the size of the system [Zakharov, 1991]. In addition, polygyny provides a higher level of heterogeneity, phenotypic diversity and tolerance in ants, therefore opening the way to formation of large interconnected settlements.

At the same time, the number of queens by itself (under either MG or PG) does not impose any restrictions on the key functions of the ant community, i.e.: (a) new family formation by newly fertilized queens (independently or by temporary social parasitism); (b) presence of auxiliary nests (polycaly); (c) sociotomy; (d) constant superfamilial structures. However, each of these functions is implemented via different scenarios in monogynous and polygynous species respectively.

(a) Polygynous species frequently use temporary social parasitism for family foundation. On the other hand, monogynous species usually establish families independently. However, pleometrosis during independent family foundation is common under both $\mathrm{MG}$ and PG.

(b) Auxiliary nests are used by all ants when the size of those nests is large enough for appropriate use.

(c) For budding, polygynous species use queens that already present in the nest, while monogynous species adopt new queens that grown either before or after separation [Schneirla, 1971; Dlussky, 1981].

(d). During formation of secondary federations, polygynous species build buffer nests between the large ones, while monogynous species utilize auxiliary nests of polycalic systems.

All characteristics listed above are related to the size and level of organization of the ant settlements. However, those characteristics consistently change through the transition of the initial family cell established by the foundress to the nest in a stable definitive condition. To make the correct comparisons between different types of settlements, we have to compare ant societies at the similar stages of their development and life history. Moreover, we need to determine the definitive status of the nest. In the course of nest development, along with the increase in the number of its inhabitants, its structure becomes more complex, and new properties that are important for the normal and stable existence of the family are acquired [Wilson, 1971; Zakharov, 1991]. The community thus obtains new characteristics, i.e. sustainable production of workers and reproductive individuals, temperature control within the nest (in the species with active thermoregulation), as well as formation of new families through sociotomy.

Certain potential for the production of new families by the ant society corresponds to the two qualitative levels of community development, i.e. two levels of its maturity [Zakharov, 1991]. The first, basic growth level is defined by the production of winged individuals. At the second level, the community is ready for sociotomy. This is the full growth level of the ant society that should be considered definitive on principle. The first level can be achieved at any number of queens in the nest. Reaching the second level is associated with the emergence of several queens per nest. In some species, this is associated with secondary polygyny. The mechanisms of maintenance of any type of polygyny (pleometrosis, primary and secondary polygyny) are generally invariable. For example, foreign queens participate in pleometrosis. The same is also true for the formation of secondary polygyny [Pisarski, 1982] and during subsequent replenishment of queens in the polygynous society (e.g. [Fortelius et al., 1993]). A close relationship between the family organization and the construction of the nest is always observed. The only mechanism for the maintenance of the integrity of ant social structures, i.e. exchange of individuals between the subsystems, is present in all types of social structures, i.e. family, colony, federation, supercolony, unicolonial structures etc. [Zakharov, 1991].

The family of each species can potentially reach the size and level of organization when the sociotomy becomes possible, i.e. the definitive level. This, however, requires favorable habitat conditions and sufficient time. Even a single observation of sociotomy for any species suggests the capability of reaching that level of organization. Thus, only species that display sociotomy at the level of the monogynous community can be considered as obligate monogynous species; for example, members of Eciton Latreille, 1804 [Schneirla, 1971] or Alloformica aberrans (Mayr, 1877) [Dlussky, 1981]. 
The present paper is dedicated to the 75 th anniversary of Alexandr P. Rasnitsyn, the prominent Russian hymenopterist and palaeontologist.

\section{References}

Adams E.S., Tschinkel W.R. 1995. Effects of foundress number on brood raids and queen survival in the fire ant Solenopsis invicta // Behavioral Ecology and Sociobiology. Vol.37. P.233242 .

Bernasconi G., Strassmann J.E. 1999. Cooperation among unrelated individuals: the ant foundress case // Trends in Ecology and Evolution. Vol.14. No.12. P.477-482.

Bondar S.S., Rusina L.Yu. 2003. [Myrmica bergi (Hymenoptera, Formicidae) at the Black Sea Biosphere Reserve] // Uspekhi sovremennoi biologii. Vol.123. P.243-248 [in Russian].

Bourke A.F.G., Franks N.R. 1995. Social evolution in ants. Princeton: Princeton University Press. 530 pp.

Debout G., Schatz B., Elios M., Mckey D. 2007. Polydomy in ants: what we know, what we think we know, and what remains to be done // Biological Journal of the Linnean Society. Vol.90. P.319-348.

Dlussky G.M. 1981. [The ants of deserts]. Moscow: Nauka. 230 pp. [in Russian].

Dlussky G.M. 1984. [Principles of organization of family in social insects] // Insect behavior. Moscow: Nauka. P.3-25 [in Russian].

Evesham E.J.M. 1985. Recognition and aggregation abilities of young workers in the polygynous ant, Myrmica rubra, for their own queens // Entomologia Generalis. Vol.10. No.2. P.77-85.

Fedoseeva E.B. 2003. [Morphological aberrations and social ontogenetic regulation in ants] // Uspekhi sovremennoi biologii. Vol.123. No.3. P.213-222 [in Russian].

Fortelius W., Rosengren R., Cherix D., Chautems D. 1993. Queen recruitment in a highly polygynous supercolony of Formica lugubris (Hymenoptera, Formicidae) // Oikos. Vol.67. P. 193199.

Hagen R.H., Smith D.R., Risssing S.W. 1988. Genetic relatedness among cofoundresses of two desert ants, Veromessor pergandei and Acromyrmex versicolor // Psyche. Vol.95. P.191-201.

Henze J. 1993. Queen-queen interactions in polygynous ants // Keller L. (ed.). Queen number and sociality in insects. Oxford Oxford University Press. P.334-361.

Henze J., Hölldobler B. 1994. Ants in the cold // Memorabilia zoologica. Vol.48. P.99-108.

Hölldobler B., Carlin N.F. 1985. Colony founding, queen dominance and oligogyny in the Australian meat ant Iridomyrmex purpureus // Behavioral Ecology and Sociobiology. Vol.18. No.1. P.45-58.

Hölldobler B., Wilson E.O. 1990. The ants. Cambridge: Belknap Press of Harvard University Press. 732 pp.

Jouvenaz D.P., Wojcik D.P., Vander Meer R.K. 1989. First observation of polygyny in fire ants, Solenopsis spp. in South America // Psyche. Vol.96. P.161-165.

Keller L. 1995. Social life: paradox of multiple-queen colonies // Trends in Ecology and Evolution. Vol.10. No.9. P.355-360.
Keller L., Passera L., Suzzoni J.-P. 1989. Queen execution in the argentine ant, Iridomyrmex humilis // Physiological Entomology. Vol.14. No.2. P.157-163.

Krasilnikov V.A. 1998. [Experimental research of primary pleometrosis in the pavement ant Tetramorium caespitum (Hymenoptera, Formicidae)] // Uspekhi sovremennoi biologii. Vol.118. No.3. P.323-330 [in Russian].

McGlynn T.P. 2010. Polygyny in thief ants responds to competition and nest limitation but not food resources // Insectes Sociaux. Vol.57. P.23-28.

Mintzer A.C. 1987. Primary polygyny in the ant Atta texana: number and weight of females and colony foundation success in the laboratory // Insectes Sociaux. Vol.34. No.2. P.108-117.

Novak M., Tarnita C.E., Wilson E.O. 2010. The evolution of eusociality // Nature. Vol.466. P.1057-1062.

Peeters C., Andersen A.N. 1989. Cooperation between dealate queens during colony foundation in the green tree ant, Oecophylla smaragdina // Psyche. Vol.96. P.39-44.

Peng R.K., Christian K., Gibb K. 1998. How many queens are cheer in mature colonies of the green ant, Oecophylla smaragdina (Fabricius)? // Australian Journal of Entomology. Vol.37. P.249-253.

Pisarski B. (ed.) 1982. Structure et organisation des sociétés de fourmis del 1'espéce Formica (Coptoformica) exsecta Nyl. (Hymenoptera, Formicidae) // Memorabilia Zoologica. Vol.38. P.1-280.

Rissing S.W., Pollock G.B. 1988. Pleometrosis and polygyny in ants // Interindividual behavioral variability in social insects. Boulder: Westview Press. P.172-222.

Schneirla T.C. 1971. Army ants: a study in social organization. San Francisco: Freeman. 349 pp.

Schrempf A., Heinze J. 2007. Back to one: consequences of derived monogyny in an ant with polygynous ancestors // Journal of Evolutionary Biology. Vol.20. P.792-799.

Starr Ch.K. 2006. Steps toward a general theory of the colony cycle in social insects // Life cycles in social insects: behaviour, ecology and evolution. St. Petersburg University Press. P.120.

Tschinkel W.R. 1992. Brood raiding in the fire ant, Solenopsis invicta (Hymenoptera: Formicidae): laboratory and field observations // Annals of the Entomological Society of America. Vol.85. P.638-646.

Tsutsui N.D., Suarez A.V. 2003. The colony structure and population biology of invasive ants // Conservation Biology. Vol.17. No.1. P.48-58.

Wilson E.O. 1971. The insect societies. Cambridge (USA): Harvard University Press. 548 pp.

Zakharov A.A. 1991. [Organization of ant communities]. Moscow: Nauka. 278 pp. [in Russian].

Zakharov A. A. 2011. [Ants: the strategy of population concentration] // Zhurnal Obshchei Biologii. Vol.72. No.4. P.269-283 [in Russian].

Zakharov A.A., Fedoseeva E.B. 2005. Nest coalitions and their status in Myrmica rubra ants (Hymenoptera, Formicidae) // Entomological Review. Vol.85. Suppl.1. P.S75-S88.

Zakharov A.A., Zakharov R.A. 2011. Immigration and formation of mixed colonies in red wood ants (Hymenoptera, Formicidae) // Entomological Review. Vol.91. No.2. P.141-151. 